\title{
LATE PLEISTOCENE GEOCHRONOLOGY OF EUROPEAN RUSSIA
}

\author{
KH. A. ARSLANOV
}

Geographical Research Institute, St. Petersburg State University, St. Petersburg 199004 Russia

\begin{abstract}
I constructed a Late Pleistocene geochronological scale for European Russia employing ${ }^{14} \mathrm{C}$ dating and paleobotanical studies of several reference sections.

\section{MIKULINO (RISS-WÜRM) INTERGLACIAL AND EARLY VALDAI (EARLY WÜRM) STAGES AND INTERSTADIALS}

I employed a modified ${ }^{230} \mathrm{Th} /{ }^{234} \mathrm{U}$ dating method (Arslanov et al. $1976,1978,1981$ ) to determine shell ages. I learned that ${ }^{232} \mathrm{Th}$ is present only in the outer layer of shells; thus, it is not necessary to correct for ${ }^{230} \mathrm{Th}$ if the surface ( $30 \%$ by weight) is removed. A great many shells were paralleldated by ${ }^{14} \mathrm{C}$ and ${ }^{230} \mathrm{Th} /{ }^{234} \mathrm{U}$ methods; results corresponded well for young shells (to $13-14 \mathrm{ka}$ ). Older shells appear to be younger due to recent carbonate contamination. Shells from transgression sediments of the Barents, White and Black Seas were chosen as most suitable for dating, based on appearance. Table 1 presents measured ages for these shells.

The data show that the inner fractions of shells sampled from Boreal (Eem) transgression deposits of the Barents and White Seas date to 86-114 ka. Shells from sediments of the Black Sea Karangat transgression, which correlates to the Boreal, date to $95-115 \mathrm{ka} .{ }^{230} \mathrm{Th} /{ }^{234} \mathrm{U}$ dating of shells and coral show that shells have younger ages than corals; this appears to result from later uranium penetration into shells (Arslanov et al. 1976). Boreal transgression sediments on the Kola peninsula can be placed in the Mikulino interglacial based on shell, microfauna, diatom and pollen studies (Arslanov et al. 1981). According to the oxygen-isotope record from deep-sea cores, interglacial substage 5e corresponds to the Dilikulino (Eem, Sangamon) interglacial in the interval 128-116 ka (Morley and Hays 1981). By considering the trend of ${ }^{230} \mathrm{Th} /{ }^{234} \mathrm{Th}$ age reduction for shells, it can be stated that the Karangat and Boreal transgressions (85-115 ka) correlate to the Mikulino interglacial.

Distinct cooling at the end of the Mikulino (Early Valdai) is identified from pollen studies of the Krotkov Cape liman clays (Taman peninsula) (Arslanov et al. 1983). Mollusk shells from the middle of the clays date to $95-100 \mathrm{ka}$ (Table 1). Tree pollen comprises $93-98 \%$ of total pollen, with $55-65 \%$ pine, $27-35 \%$ fir and $12 \%$ birch. This association indicates taiga forest. According to oxygen-isotopic, micropaleontologic and geochronologic investigations of ocean sediments, coral terraces and continuous lake and bog sections, abrupt climatic cooling occurred from 116-110 ka (Würm I). The Kurgolovo stage of the Russian plain glacial zones appears to correspond to this cooling. During the Mikulino interglacial and Early Valdai interstadial, loess loams interbedded with soil horizons were deposited in Russian plain periglacial regions (Velichko 1977). Two worldwide transgressions occurred in the Early Würm at $c a$. 100-105 and 80-85 ka BP and are recorded by the presence of emerged coral terraces on Barbados, in the eastern Caribbean Sea, and New Guinea and Timor, in the southwest Pacific Ocean.

Widespread continental sediments of two Early Würm interstadials (Amersfort/Brerup and Odderade in western Europe, Tarasovo and Kruglizky in Belorussia, Jonenis I and Jonenis II in Lithuania) correspond to the two oceanic transgressions discussed above. These sediments are well defined in the Grande-Pile section (France) and correspond to substages $5 \mathrm{c}$ and $5 \mathrm{a}$ of the oxygenisotope scale (Woillard and Mook 1982). 
TABLE $1 .{ }^{230} \mathrm{Th} /{ }^{234} \mathrm{U}$ Ages of Marine Mollusk Shells from Barents, White and Black Sea Transgression Sediments $(\mathrm{A}=$ outer fraction, $\mathrm{B}=$ inner fraction $)$

\begin{tabular}{|c|c|c|}
\hline $\begin{array}{l}\text { Laboratory } \\
\text { number }\end{array}$ & Age & Mollusk species and location \\
\hline LU-455B & $97,000 \pm 4000$ & $\begin{array}{l}\text { Cyprina islandica from the section base, Svjatonossky gulf, Kola } \\
\text { peninsula }\end{array}$ \\
\hline LU-452A & $102,000 \pm 4000$ & Astarta borealis from the Malaja \\
\hline LU-452B & $114,000 \pm 4000$ & Kachovka exposure, Kola peninsula \\
\hline LU-464A & $85,500 \pm 3200$ & Cyprina islandica from the exposure \\
\hline LU-464B & $86,000 \pm 3900$ & On Chapoma River, Kola peninsula \\
\hline LU-808A & $129,400 \pm 4900$ & $\begin{array}{l}\text { Cardium edule from the marine sediments of Maly Kut section, Taman } \\
\text { peninsula }\end{array}$ \\
\hline LU-808B & $115,000 \pm 3100$ & Same as above \\
\hline LU-805A & $125,000 \pm 5000$ & $\begin{array}{l}\text { Paphia senessens from the middle part of the marine sediments of } \\
\text { Eltigen section, eastern coast of Kerch strait }\end{array}$ \\
\hline LU-805B & $102,290 \pm 3200$ & $\begin{array}{l}\text { Paphia senessens frem the middle part of the marine sediments of } \\
\text { Eltigen section, eastern coast of Kerch strait }\end{array}$ \\
\hline LU-802A & $90,600 \pm 3100$ & Cardium tuberculatum from the same layer \\
\hline LU-802B & $107,400 \pm 3800$ & Cardium tuberculatum from the same layer \\
\hline LU-804-1A & $88,900 \pm 2200$ & $\begin{array}{l}\text { Cardium edule from the Krotkov cape section, western part of Taman } \\
\text { peninsula }\end{array}$ \\
\hline LU-804-1B & $98,000 \pm 2400$ & Same as above \\
\hline LU-804-2A & $98,900 \pm 2200$ & Same as above \\
\hline LU-804-2B & $100,500 \pm 2100$ & Same as above \\
\hline
\end{tabular}

Early Valdai interstadials followed the main Early Valdai (Würm) glacial stage. This interstadial (isotopic stage 4) ranges from 72-58 ka (Morley and Hays 1981); the polar front migrated south to $45^{\circ} \mathrm{N}$ latitude (Ruddiman and McIntire 1977). Scandinavian ice sheets expanded south to $\sim 60^{\circ} \mathrm{N}$ latitude only during this stage; southernmost Sweden (Sconia) was not affected by Würm glaciation earlier than $21 \mathrm{ka}$ (Berglund and Lagerlund 1981).

Early Valdai sediments were studied in the following sections: Shestichino in the Jaroslavi region, Kileshino (near Selizharovo) in the Tver region and Migovo (near Grodno) in Belorussia. According to paleobotanical data (F. J. Velichkevich and E. A. Spiridonova), these sediments deposited in tundra and tundra-forest conditions date to >47-49 ka (Arslanov 1975; Spiridonova et al. 1981). To date, the Early Valdai (Visla) glacial moraine cannot be identified on the Russian plain, nor over much of western Europe.

\section{THE MIDDLE VALDAI NON-GLACIAL INTERVAL}

The interval between Early and Late Valdai glaciation includes the Middle Valdai interstadial complex (mega-interstadial), which contained warming and cooling phases. ${ }^{14} \mathrm{C}$ dating of plant remains shows that the Middle Valdai (Würm, Visla) mega-interstadial continued from 58-60 to $25 \mathrm{ka}$ (Arslanov 1975; Woillard and Mook 1982), and according to the oxygen-istope scale, from 27 to $58 \mathrm{ka}$ (Morley and Hays 1981).

Data from 31 Middle Valdai sediment sections are listed in Table 2, and include only those studied by palynological or paleocarpological methods. The oldest date was determined for the Rokai section near Kaunas: $52 \mathrm{ka} \pm 1.69 \mathrm{ka}$. Pollen data indicate that tundra-forest vegetation expanded at this time (Gajgalas et al. 1987). 
TABLE 2. ${ }^{14} \mathrm{C}$ Dates of Organic Remnants from Middle Valdai Sediments

\begin{tabular}{|c|c|c|}
\hline Lab no. & ${ }^{14} \mathrm{C}$ age (BP) & Section location, sample material, depth \\
\hline LU-28C & $25,440 \pm 270$ & Dunaevo, Lovat River basin, peat from $6.4 \mathrm{~m}$ \\
\hline LU-28B & $25,600 \pm 360$ & Dunaevo, Lovat River basin, peat from $6.4 \mathrm{~m}$ \\
\hline LU-1237 & $26,980 \pm 590$ & Njom, Vychegda river basin, peat from $5.2 \mathrm{~m}$ \\
\hline LU-105 & $28,170 \pm 750$ & Belorussia; plant detritus \\
\hline LU-646 & $29,080 \pm 580$ & Novomonchalovo, near t. Rzhev, Tver region, wood \\
\hline LU-107 & $31,470 \pm 590$ & Shenskoje, at Kesma River, Tver region, wood from $4.5 \mathrm{~m}$ \\
\hline LU-339 & $32,650 \pm 720$ & Shenskoje, Kesma river exposure, Tver region, borehole, peat from $9.7-10 \mathrm{n}$ \\
\hline LU-1319 & $31,100 \pm 730$ & Mamyl, Pechora River, Komi Republic, peat from $13 \mathrm{~m}$ \\
\hline LU-159 & $32,260 \pm 730$ & Lejasziemes, Gauja River, Latvia, plant detritus from upper layer \\
\hline LU-311 & $34,500 \pm 790$ & Lejasziemes, Gauja River, Latvia, plant detritus from lower layer \\
\hline LU-1633 & $33,460 \pm 1060$ & Birzhai, Lithuania, borehole \\
\hline LU-1149A & $33,100 \pm 850$ & Michalinovo, near Vitehsk, Belorussia, plant detritus, coarse fraction \\
\hline LU-1149B & $34,040 \pm 350$ & Michalinovo, near Vitehsk, Belorussia, plant detritus, fine fraction \\
\hline LU-645 & $33,690 \pm 360$ & Novomonchalovo, near t. Rzev, Tver region, wood \\
\hline LU-513A & $33,520 \pm 470$ & Sozva River, Lower Pechora basin, peat, insoluble fraction \\
\hline LU-513B & $34,540 \pm 1570$ & Same sample, soluble (in $2 \% \mathrm{NaOH}$ ) fraction \\
\hline LU-92A & $36,400 \pm 800$ & Shapurovo, near Surazh, Belorussia, peat \\
\hline LU-1620 & $36,360 \pm 1300$ & Shapurovo, near Surazh, Belorussia, peat \\
\hline LU-98 & $37,960 \pm 1000$ & Sloboda, near Surazh, Belorussia, peat \\
\hline LU-150 & $37,200 \pm 910$ & Vjazynka, $30 \mathrm{~km} \mathrm{NW}$ from Minsk, peat \\
\hline LU-599 & $38,230 \pm 240$ & Dzhiguta, near Sukhumi, wood from $1.75-1.90 \mathrm{~m}$ \\
\hline LU-512A & $38,670 \pm 870$ & Tyrybei, Hvostovaja River, Lower Pechora basin, peat, insoluble fraction \\
\hline LU-512B & $39,840 \pm 570$ & Tyrybei, Hvostovaja River, Lower Pechora basin, peat, soluble fraction \\
\hline LU-588 & $39,170 \pm 470$ & Kyltovka, Vychegda River basin, Komi ASSR., wood from 4.7-4.9 m \\
\hline LU-63 & $39,800 \pm 800$ & Grazhdansky prospect borehole, $N$ Leningrad, peat \\
\hline LU-22 & $40,380 \pm 800$ & Grazhdansky prospect borehole, $\mathrm{N}$ Leningrad, peat \\
\hline LU-15A & $40,490 \pm 870$ & Kashin, Tver region, coarse fraction \\
\hline LU-15B & $41,700 \pm 730$ & Same sample, fine fraction \\
\hline LU-550 & $40,650 \pm 790$ & Shapkino II, Shapkina River, lower Pechora basin, peat \\
\hline LU-517B & $40,860 \pm 1260$ & Shapkino II, Shapkina River, lower Pechora basin, peat \\
\hline LU-94 & $40,800 \pm 1900$ & Suchona near v. Selische, Vologda region, peat from $20.0-20.2 \mathrm{~m}$ \\
\hline LU-93 & $41,100 \pm 1500$ & Same borehole, peat from $19.75-20.0 \mathrm{~m}$ \\
\hline LU-632 & $41,810 \pm 600$ & Kileshino, near Selizharovo, Tver region, wood \\
\hline LU-648 & $41,200 \pm 710$ & Dzhiguta, near Sukhumi, wood from $3.7-3.9 \mathrm{~m}$ \\
\hline LU-647A & $42,760 \pm 660$ & Dzhiguta, near Sukhumi, wood from $4.7-4.8 \mathrm{~m}$ \\
\hline LU-606 & $44,130 \pm 630$ & Dzhiguta, near Sukhumi, wood from $5.0-5.1 \mathrm{~m}$ \\
\hline LU-181 & $41,290 \pm 320$ & Dolgopolka, near Tutaev, Jaroslavl region, wood \\
\hline LU-533 & $42,810 \pm 1200$ & Urdjuga, Malozemelskaja tundra, peat \\
\hline LU-519 & $42,660 \pm 970$ & Shapkina I, Shapkina River, lower Pechora basin, peat \\
\hline LU-596 & $43,300 \pm 780$ & Vaskelovo, near Leningrad, peat \\
\hline LU-1053 & $43,440 \pm 1460$ & Jula, Pinega river basin, Arkhangelsk region, peat \\
\hline LU-1262 & $45,000 \pm 1150$ & Same exposure, wood \\
\hline LU-1206 & $45,210 \pm 1430$ & Juizh, North Dvina basin, Arkhangelsk region, peat \\
\hline LU-673 & $45,770 \pm 1160$ & Chernaja Rechka, near Leningrad, peat from $2.8 \mathrm{~m}$ \\
\hline LU-164 & $46,030 \pm 1710$ & Krasnaja Gorka, Dneiper River, Belorussia, peat from $6-7 \mathrm{~cm}$ top peat layer \\
\hline LU-186 & $46,770 \pm 830$ & Krasnaja Gorka, Dneiper River, Belorussia, peat from $12-15 \mathrm{~cm}$ \\
\hline LU-133 & $45,260 \pm 800$ & Krasnaja Gorka, Dneiper River, Belorussia, peat from $18-21 \mathrm{~cm}$ \\
\hline LU-624 & $46,880 \pm 1270$ & Bor, exposure on Lower Pechora, peat \\
\hline LU-674 & $47,410 \pm 1270$ & Chernaja River, Bolshezemelskaja tundra, wood \\
\hline LU-566 & $47,520 \pm 1000$ & Kyltovka, Vychegda River basin, wood from $11.1-11.3 \mathrm{~m}$ \\
\hline LU-601 & $47,320 \pm 1050$ & Dzhiguta, near Sukhumi, wood from $5.85-5.95 \mathrm{~m}$ \\
\hline LU-1438 & $52,000 \pm 1690$ & Rokaj, near Kaunas, Lithuania, wood \\
\hline
\end{tabular}


At 48-45 ka BP, climatic conditions in the northeastern Russian plain (North Dvina, Vychegda and Pechora basins) were similar to the present (Arslanov et al. 1980b, 1984). From 45-42 ka, cooling had set in. A grass community of wormwoods and a yernik-tundra were widespread at the time. Later, between $42.5 \mathrm{ka}$ and $38 \mathrm{ka}$, warming occurred and forest vegetation appeared (Arslanov et al. 1980b).

Two warming phases can be distinguished during the Middle Valdai. The first, the Krasnogorsky (Rokai) and "Grazhdansky prospect" interstadials, occurred in the interval, $52 \mathrm{ka}-36 \mathrm{ka}$. Cooling occurred at $45 \mathrm{ka}-42.5 \mathrm{ka}$ on the northeastern Russian plain. The second Middle Valdai warming, the Dunaevo interstadial (Brjansk interval in periglacial regions) took place from $32 \mathrm{ka}-25 \mathrm{ka}$. The Lejasziemes cooling interval (36 ka-32 ka) divided these two warm phases. At the cooling maximum, $34 \mathrm{ka}-33 \mathrm{ka}$, grass tundra was present in Latvia (Lejasziemes), in northeastern Belorussia (Michalinovo) and in the Lower Pechora basin (Soz'va) (Arslanov et al. 1980b, 1981; Yoznjachuk et al. 1981). This major northern hemisphere cooling was noted in western Europe (between the Denekamp and Hengello interstadials) in Siberia (Konoshelsk climatic deterioration) and in North America (Cherrytry glacial stage).

During the Dunaevo interstadial on the Russian plain, birch-pine and fir-pine forests dominated in the northeast (Dunaevo), central (Shenskoje, Novomongolovo) and northwest regions (Spiridonova et al. 1981). The three climatic phases, interstadial "Grazhdansky prospect" (45 ka-36 ka), Lejasziemes cooling (36 ka-32 ka) and Dunaevo interstadial (32 ka-25 ka), are comparable to three climatic phases in Siberia, western Europe and North America during the same period. These phases also correspond to oxygen-isotope stage 3 (Arslanov 1975).

Abrupt Middle Valdai warming was observed in middle and high latitudes from west to east (Arslanov 1975). During its optimum (48 ka-45 ka and $42 \mathrm{ka}-39 \mathrm{ka}$ ), low bush-tundra dominated in regions adjoining the Atlantic Ocean and North Sea; forest tundra was present near the northern taiga border, in Belorussia, and a northern taiga was present in northwestern and central regions of the Russian plain. Taiga forests similar to recent ones spread north of the Dvina River and Vychegda basin. Discontinuous fir-pine-birch forests of the northern Pechora basin are expanded to the Barents Sea coast, farther north than at present.

From $48 \mathrm{ka}$ to $45 \mathrm{ka}$, the forest formation (Shapkino I, II, Sozva, Ghernaja River, Urduga, Tarubei sections) was distributed on the area of recent forest tundra, Bolszezemelskaja and Alozemelskaja (Arslanov et al. 1980b). Obviously, Middle Valdai optima were typical interstadial stages in western and central regions of the Russian Plain. The interglacial is termed the Kargino in Siberia. A mirror-like situation was observed in Canada (Lamb 1977). Thus, Europe and eastern North America were under cold climatic conditions in the Middle Würm. This could be a result of 1) the close proximity of the Laurentian and Scandian continental ice sheets; 2) a warm current, the Gulf Stream, circulated no farther than $55^{\circ} \mathrm{N}$ (Ruddiman and McIntire 1977), causing cooling in western Europe and in the western part of the Russian plain. Regions distant from the Laurentian and Scandian ice sheets and from the cold Atlantic Ocean (northeastern Russian Plain, Siberia, central and western Canada) were under interglacial climatic conditions in the Middle Würm. This was probably caused by high summer insolation in the high latitudes at 55-40 ka. The degree of insolation was just below that during the Mikulino interglacial and Holocene optimum (Arslanov 1975 , 1982). Comparison of climatic-geochronologic data for two sections, Chernaja near the Barents Sea and Dziguta near Sukhumi, revealed that the Chernaja area had a coniferous forest with small birch admixture at $47 \mathrm{ka}$ (Middle Valdai optimum) instead of recent forest-tundra. At the same time, silver fir and spruce forest with beech admixture dominated in the Sukhumi region; such vegetation can be observed now at $\geq 1200 \mathrm{~m}$ asl (Arslanov et al. 1980a). 


\section{LATE VALDAI GLACIAL STAGE AND DEGLACIATION}

The Valdai glacial maximum has not been definitely dated. Some scientists believe the Early Valdai stage to be the maximum. I believe that the maximum occurred in the Late Valdai, based on ${ }^{14} \mathrm{C}$ dates from organic remains from sediments overlain by moraine deposits of the glacial maximum from western Belorussia to the Pechora basin. Table 3 shows data for eight sections. Other results suggest that submoraine organic layers formed during the Middle Valdai non-glacial interval. There appear to be no Middle Valdai glacial intervals in western Europe nor on the Russian plain, so the Middle Valdai age of submoraine sediments indicates that overlying glacial sediments were deposited during Late Valdai glaciation. This conclusion is supported by oxygen-isotopic data, with the maximum southward drift of the polar front at $17 \mathrm{ka}-18 \mathrm{ka}$ and by

TABLE 3. ${ }^{14} \mathrm{C}$ Ages of Valdai Submoraine Organic Sediments

\begin{tabular}{|c|c|c|}
\hline Lab no. & Age & Section location, sample material \\
\hline LU-616A & $16,650 \pm 150$ & Rubezhniza, $7 \mathrm{~km} \mathrm{SE}$ of Liosno, Belorussia, plant detritus \\
\hline LU-616B & $19,270 \pm 770$ & Same sample, soluble (in $2 \% \mathrm{NaOH}$ ) fraction \\
\hline LU-1148A & $16,950 \pm 120$ & Chizhovka, Dubrovno region, near Vitebsk, plant detritus \\
\hline LU-1148C & $16,540 \pm 150$ & Same sample, soluble fraction \\
\hline LU-95A & $17,700 \pm 170$ & Drichaluki, $2.5 \mathrm{~km} \mathrm{~N}$ of Surazh, Belorussia, plant detritus, upper layer \\
\hline LU-96 & $18,370 \pm 180$ & Drichaluki, plant detritus, middle layer \\
\hline LU-1756 & $19,780 \pm 150$ & Drichaluki, plant detritus, middle layer \\
\hline LU-1810 & $17,430 \pm 1780$ & Drichaluki, arcto-boreal plants \\
\hline LU-1619 & $24,690 \pm 370$ & Drichaluki, plant detritus, lower layer \\
\hline LU-1618 & $21,110 \pm 590$ & Drichaluki, plant detritus, lower layer, arcto-boreal \\
\hline LU-615A & $21,080 \pm 340$ & Kasplane, $5 \mathrm{~km}$ from Surazh, plant detritus \\
\hline LU-615B & $19,550 \pm 190$ & Same sample, soluble fraction \\
\hline LU-91 & $22,500 \pm 210$ & Shapurovo, $3 \mathrm{~km}$ SE of Surazh, plant detritus from $1.8 \mathrm{~m}$ \\
\hline LU-18B & $21,410 \pm 150$ & $\begin{array}{l}\text { Puchka, near v. Pokrovskoje, Kubenskoje Lake basin, Vologda region, } \\
\text { peat and wood from } 6.2 \mathrm{~m}\end{array}$ \\
\hline LU-18A & $21,880 \pm 110$ & Same sample, cellulose \\
\hline LU-90A & $25,100 \pm 240$ & Gozha, $13 \mathrm{~km} \mathrm{~N}$ of Grodno, Neman River, peat, fraction $\geq 1 \mathrm{~mm}$ \\
\hline LU-90B & $24,860 \pm 230$ & Same sample, fraction $\leq 1 \mathrm{~mm}$ \\
\hline LU-1616A & $26,610 \pm 220$ & Irkhino, western bank of Kubenskoje lake, Vologda region, peat \\
\hline LU-1616B & $32,090 \pm 450$ & Same layer, wood \\
\hline LU-1149A & $33,100 \pm 850$ & $\begin{array}{l}\text { Mikhalinovo, } 8 \mathrm{~km} \mathrm{SW} \text { of Liosno, Belorussia, plant detritus, fraction } \\
\geq 0.25 \mathrm{~mm}\end{array}$ \\
\hline LU-1149B & $34,040 \pm 350$ & Same sample, fraction $\leq 0.25 \mathrm{~mm}$ \\
\hline LU-1257 & $34,030 \pm 810$ & Tomasha, Tomasha river, $3.6 \mathrm{~km}$ from the mouth, Arkhangelsk, gyttja \\
\hline LU-399 & $38,900 \pm 480$ & $\begin{array}{l}\text { Kileshino, } 4 \mathrm{~km} \mathrm{~N} \text { of Selizharovo, Tver region, wood from peat lens in } \\
\text { moraine }\end{array}$ \\
\hline LU-525 & $39,610 \pm 490$ & Kileshino, wood from peat lens in moraine \\
\hline LU-527 & $46,670 \pm 910$ & Same exposure, wood from moraine \\
\hline LU-632 & $41,810 \pm 600$ & Same section, wood under sand, with gravel and boulder \\
\hline LU-513A & $33,520 \pm 470$ & $\begin{array}{l}\text { Sozva-1, Sozva river, tributary of the Pechora River, peat under limno- } \\
\text { glacial sediments }\end{array}$ \\
\hline LU-1113 & $40,680 \pm 1180$ & Sozva-2, the section at the same locality, peat under moraine \\
\hline LU-533 & $42,810 \pm 1200$ & Urdjuga, Sula River basin, Pechora tributary, peat under moraine \\
\hline (5 dates) & $\begin{array}{l}40,650 \pm 790 \text { to } \\
45.280 \pm 1200\end{array}$ & Shapkina I, II, Shapkina River, Lower Pechora basin; peat under moraine \\
\hline
\end{tabular}


CLIMAP data on the maximum distribution of the Laurentian and Scandian ice sheets at $18 \mathrm{ka}-20$ ka (Belenger 1982; CLIMAP 1975, 1985).

Short-term warming occurred after the Late Pleistocene glacial maximum (Arslanov 1975). Organic sediments correlated with the interval mentioned above have not been identified on the Russian plain. This phase was followed by abrupt cooling 16.5-15 ka; morainal Veps-stage sediments formed on the Russian plain at this time. Events following the second glacial maximum are established: Raunis, Bølling, Allerød, divided by Oldest, Older, and Younger Dryas cooling. Recently, two new Raunis interstadial sections were studied in Latvia: Burzava and Jidumnicki (Arslanov et al. 1981). Interstadial peat dates to $13 \mathrm{ka}$.

\section{CONCLUSION}

Table 4 presents the Late Pleistocene time scale for European Russia. Names of interstadials and cooling phases correspond to the names of sections where they were first studied (Dunzaevo, Lejasziemes, Michalinovo, "Grazhdansky prospect", Shapkina, Krasnaja Gorka, Shestichino, Jonenis I, II, Tosno).

TABLE 4. Late Pleistocene Geochronology Scale of European Russia

\begin{tabular}{|c|c|c|}
\hline Climatic-geochronologic subdivision & Age $\left(\times 10^{3}\right) \mathrm{BP}$ & Oxygen isotope stage \\
\hline Holocene & $10.0-0$ & 1 \\
\hline \multicolumn{3}{|l|}{ Valdai glaciation } \\
\hline \multicolumn{3}{|l|}{ Late Valdai stages and interstadials } \\
\hline Younger Dryas & $11.0-10.0$ & 2 \\
\hline Allerød & $11.8-11.0$ & 2 \\
\hline Older Dryas & $12.0-11.8$ & 2 \\
\hline Bølling & $12.4-12.0$ & 2 \\
\hline Oldest Dryas & $12.4-13.0$ & 2 \\
\hline Raunis interstadial & $13.7-13.0$ & 2 \\
\hline Veps stage & $15.0-13.7$ & 2 \\
\hline Climatic amelioration & $16.5-15.0$ & 2 \\
\hline \multicolumn{3}{|l|}{ Max stage } \\
\hline Bologoje - Edrovo stage & $25.0-16.5$ & 2 \\
\hline \multicolumn{3}{|l|}{ Middle Valdai mega-interstadial } \\
\hline Dunaevo (Brjansk) interstadial & $32.0-25.0$ & 3 \\
\hline Lejaszieme (Michalinovo) & & 3 \\
\hline Climatic deterioration & $36.0-32.0$ & 3 \\
\hline Interstadial "Grazdanskij prospect" & $42.5-36.0$ & 3 \\
\hline Shapkino climatic deterioration & $45.0-42.5$ & 3 \\
\hline Krasnogorsk (Rokaj) interstadial & $58.0-45.0$ & 3 \\
\hline \multicolumn{3}{|l|}{ Early Valdai stages and interstadials } \\
\hline Shestikhino climatic deterioration & $72.0-58.0$ & 4 \\
\hline Kruglizy interstadial (Jonenis II) & $85.0-72.0$ & $5 a$ \\
\hline Climatic deterioration & $95.0-85.0$ & $5 b$ \\
\hline Tosno interstadial (Jonenis I; Upper Volga) & $1050-95.0$ & $5 c$ \\
\hline 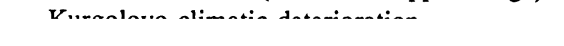 & $\cdots \ldots$ & $\cdots$ \\
\hline
\end{tabular}




\section{REFERENCES}

Arslanov, Kh. A. 1975 Upper Pleistocene radiocarbon geochronology of the European part of USSR. Bulletin of the Commission for Studies in the Quaternary Period 43: 3-25.

1982 Radiocarbon chronology of the Valdaj Epoch on the Russian Plain. Abstract. Moscow, XI INQUA Congress 2: 12.

1987 Radiocarbon: Geochemistry and Geochronology. Leningrad, Leningrad University Press: 300 p.

Arslanov, Kh. A., Evzerov, V. Ja., Tertychny, N. I., Gerasimova, S. A. and Lokshin, N. V. 1981 On the age of Boreal transgression sediments on the Kola peninsula. In Pleistocene Glaciation on the EastEuropean Plain. Moscow: 28-37.

Arslanov, Kh. A., Gej, N. A., Izmajlov, Ja. A., Lokshin, N. V., Gerasimova, S. A. and Tertychny, N. I. 1983 On the age and climatic conditions of sediment formation on Late Pleistocene sea terraces on the Kerch strait coast. Vestnik Leningradskogo Universiteta 12: 69-80.

Arslanov, Kh. A., Gej, N. A., Ljadov, V. V. and Tertychnaja, T. V. 1980a New data on Middle Würm geochronology and paleogeography in Abkhazia. In Geokhronologija Chetvertichnogo Perioda. Moscow: 131-138.

Arslanov, Kh. A., Kondratene, O. P., Krukle, M. Ja., Stelle, V. A. and Ljadov, V. V. 1981 On the geochronology and paleogeography of the Xaunis interstadial in the Late Pleistocene in Latvia. Vestnik Leningradskogo Universiteta 6: 96-102.

Arslanov, Kh. A., Lavrov, A. S., Ljadov, V. V., Nikiforova, L. D., Potapenko, L. M. and Tertychnaja, T. V. 1980b Radiocarbon geochronology and paleogeography of the Middle Valdaj interval and last glacial shield on the northeast Russian Plain. Moscow, Geokhronologija Chetvertichnogo Perioda: 68-81.

Arslanov, Kh. A., Levina, N. B., Ostanin V. E., Baranova, V. N., Smirnova, V. M. and Tertychnaja, T. V. 1984 On the geochronology and paleogeography of the Late Pleistocene and Early Holocene in the North Dvina basin. VestnikLeningradskogo Universiteta 12: 57-66.

Arslanov, Kh. A., Tertychny, N. I., Gerasimova, S. A. and Lokshin, N. V. 1976 Sea mollusk shell dating by the ${ }^{230} \mathrm{Th} /{ }^{234} \mathrm{U}$ method. Geokhimija 11: 1724-1734.

Arslanov, Kh. A., Tertychny, N. I., Lokshin, N. V., Gerasimov, S. A., Tertychnaja, T. V., Filonov, B. A. and Chernov, S. B. 1978 Study of ${ }^{14} \mathrm{C}$-concentration variations in surface sea waters by ${ }^{14} \mathrm{C}$ and ${ }^{230} \mathrm{Th} /{ }^{234} \mathrm{U}$ dating of marine shells. In Astrophysical Phenomena and Radiocarbon. Tbilisi, Tbilisi University Press: 407-422.

Belenger, R. E. 1982 Paleooceanography of the Norwegian Sea during the past 130,000 years: Coccolithophorid and foraminiferal. Boreas 11(1): 29-36.

Berglund, B. E. and Lagerlund, E. 1981 Eemian and Weichseliam stratigraphy of south Sweden. Boreas 10(4): 323-362.

CLIMAP Project Members 1976. Science 191: 11311137.

Gajgalas, A. I., Arslanov, Kh. A., Banis, Ju. Ju., Kazarzeva, T. I. and Tertychnaja, T. V. 1987 Radiocarbon data of Late Pleistocene, Holocene and archaeological sites in Lithuania. New Data on the Geochronology of the Quaternary Period. Moscow, Nauka: 88-97.

Lamb, H. H. 1977 Climatic analysis. Philosophical Transactions of the Royal Society of London B280: 341-350.

Morley, J. J. and Hays, J. D. 1981 Toward a high-resolution, global deep-sea chronology for the last 75,000 years. Earth and Planetary Science Letters 53(3): 279-295.

Ruddiman, W. F. and McIntire, A. 1977 Late Quaternary surface ocean kinematics and climatic change in the high-latitude North Atlantic. Journal of Geophysical Research 82(27) 3877-3887.

Spiridonova, E. A., Arslanov, Kh. A., Malakhovskij, D. B., Velichkevich, F. Ju., Denisenkov, V. P., Latysheva, N. M. and Ljadov, V. V. 1981 Pleistocene sediment section near Selizharovo (Upper Volga). In Palynology of the Pleistocene and Holocene. Leningrad, Leningrad University Press: 32-45.

Velichko, A. A. 1977 A trial of paleogeographic reconstruction of Upper Pleistocene conditions for the European part of USSR. Izvestija Akademii Nauk SSSR, Serija Geographicheskaja 4: 28-44.

Voznjachuk, L. N., Sanko, A. F., Arslanov, Kh. A., Ljadov, V. V. and Tertychnaja, T. V. 1981 On the geochronology and paleogeography of the Middle and Late Valdaj in the eastern part of the Belorussian lake region. Isotopic and Geochemical Methods in Biology, Geology and Archeology. Tartu, Estonian SSR Academy of Science: 24-27.

Woillard, G. M. and Mook, W. G. 1982 Carbon-14 dates at Grande Pile: Correlation of land and sea chronologies. Science 215: 159-161. 